\title{
Methodology for Carbon Footprint Calculation Towards Sustainable Innovation in Intangible Assets
}

\author{
Edurne Loyarte-López ${ }^{1, *}$, Mario Barral ${ }^{1}$ and Juan Carlos Morla ${ }^{2}$ \\ 1 Vicomtech, 20009 San Sebastián, Spain; mbarral@vicomtech.org \\ 2 Sonder Consulting, 48630 Elexalde-Gorliz, Spain; jcmorla@sonderconsulting.es \\ * Correspondence: eloyarte@vicomtech.org
}

Received: 30 January 2020; Accepted: 19 February 2020; Published: 21 February 2020

\begin{abstract}
Calculating the carbon footprint is fundamental to understand how an organization's activities impact global sustainability. The main challenge is how to calculate it when environmental aspects are intangible assets. The present paper investigates in what ways the environmental effects of 13 aspects in relation with $R \& D$ activities in an applied research center could contribute to sustainable development. For this purpose, we described methodology to routinely measure greenhouse gas (GHG) emissions and calculate the carbon footprint (CF) of all research activities related to intangible assets (R\&D projects, researchers' knowledge and software libraries) with real-time data being provided. Selection of conversion factors to express all GHG emissions are described, in particular those related to air travel on account of its greatest contribution to CF. In addition, these data were used as a factor in assessing the environmental impact of the center, under ISO 14001. As a result, our center can manage its $\mathrm{CF}$ and make decisions about how to enhance sustainability awareness at all levels of the organization and gradually improve $\mathrm{CF}$ data, of which the main contributors were transportation and travel (66.4\%) and electricity (33.1\%) in 2018.
\end{abstract}

Keywords: carbon footprint; sustainability awareness; environmental impact; intangible assets; research; innovation

\section{Introduction}

The results of surveys requested by the European Commission, in 2012, [1] indicated that approximately $52 \%$ of European citizens believe that companies have a positive influence on society, with $71 \%$ thinking that, compared with large companies, small and medium size enterprises (SME)s make efforts to behave responsibly. However, regardless of their size and sector, companies and organizations can play a meaningful role in building a more sustainable planet. It requires integrating the concept of sustainability with business, which entails environmentally friendly economic growth together with a commitment to social welfare [2]. In this vein, the European Commission implemented an action plan to build a circular economy in order to minimize resource use and foster materials' reuse, recovery and recyclability down the road [3]. Transition towards sustainability with a circular perspective will require a joint effort by all concerned parties, and dialogue among involved stakeholders should be enhanced. This transformation based on circulatory principles should also lead to changes in people's consumption behavior and waste management [4]. Likewise, collaboration among heterogeneous actors (e.g., informal collaborations, strategic alliances, joint ventures, partnerships, R\&D consortia, associations, clusters, and networks) facilitates knowledge diffusion and learning to be applied in cross-cutting issues, such as the management of climate change [5]. Within this framework of environmental awareness, any responsible action, even at small scale, might help pave the way towards large-scale changes in global sustainability. 
The identification and calculation of intangible assets are difficult and fuzzy in different disciplines such as intellectual capital, research performance, and also the carbon footprint since it is required to convert intangible (knowledge) into tangible indicators [6,7]. This research project contributes to identify environmental aspects related to technological research in intangible assets, which are used to measure the environmental dimension of sustainable development. Thus, the center measures greenhouse gas (GHG) emissions of every aspect identified, the sum of which gives its carbon footprint (CF) based on intangible assets. Toward optimum performance, the center controls and continuously improves its daily activities on a voluntary basis under international standard certifications for quality management [8], R\&D management [9], and environmental management [10]. In addition, specific training actions are implemented for different levels of responsibility, as, paraphrasing E. Sidiropoulos [11], sustainability is considered a "learning journey". In addition to the actions described above, the center considers it necessary to boost awareness of environmental impacts when dealing with intangible assets, as the ability to perceive, feel, or be conscious of environmental issues has a positive and significant influence on environmental behaviors [12].

Therefore, to improve the visibility of such impacts, greenhouse gas emission (GHG) accounting and $\mathrm{CF}$ calculation in real time should be included, considering their influence on global warming and climate change [13-15].

Accordingly, throughout this article the following questions will be responded to:

- Is an organization based on intangibles assets able to contribute to climate change?

- Is CF a suitable indicator for measuring the effect of R\&D activities on the environment?

- Could CF become an element for raising environmental awareness within the organization?

This paper is divided into four sections. The first section sets out the context, background, and methodology. Theorical framework and methods allow to establish assumptions and calculate $\mathrm{CF}$, which is the main challenge of this article. Section 3 explains the results by describing $\mathrm{CF}$ as environmental indicators, calculation processes, and a benchmarking exercise. Finally, Sections 4 and 5 present the study's discussion and conclusions.

\section{Materials and Methods}

\subsection{The Context of the Organization}

This research work was conducted in a technology center (research technology organization), of which the R\&D activities are focused on Information and Communication Technologies (ICT). Currently, the staff complement of the center, located in the Basque Country (northern Spain), numbers approximately 140 employees.

At the center, research activities on software-based technologies are performed using diverse computer systems in an office-like setting, which normally has an extremely low environmental risk. Consequently, the environmental impacts of direct or indirect consumption and generated waste, even if high, are not as easily perceived, as are those of organizations with higher environmental risk. Such higher-risk organizations include those that require using dangerous substances, such as chemicals or biological substances, with specific conditions for handling, storage, and disposal, which all make their environmental impacts more conspicuous.

Within this framework, the challenge is to impart visibility to environmental impacts related to intangible assets in order to measure and control them, with the aim of achieving more sustainable innovation in all the research areas. Some time ago, the center had committed to raising staff awareness of environmental concerns. This endeavor included disseminating such concerns to all levels of the organization by formulating and implementing guidelines and action plans (i.e., environmental management, certification under ISO 14001, specific training and briefings, environmental management procedures, and the like).

In recent years, the center has gone a step further and implemented methodology to analyze the GHG emissions generated by all its activities. An in-house-designed Information Technology (IT) 
application facilitates staff consciousness of GHG emission data in all stages of projects, as these are updated continuously.

The contribution of this study to existing research is to develop and implement methodology for $\mathrm{CF}$ calculation generated by intangible assets and integrate it into environmental management. The contribution of environmental aspects (consumptions and wastes) to total CF (as a percentage) is therefore used as another factor in the assessment of their environmental impacts according to the ISO 14001 standard. The aim of this methodology is to become an element of continuous awareness on the environmental impact of activities dealing with intangible assets, which is by nature less noticeable. Linking certified environmental management with CF calculation is a complementary action to augment environmental responsibility of the center's employees and other stakeholders.

\subsection{Background}

We conducted a literature review to determine the latest developments in identifying sources of and measuring GHG emissions and the role of organizations to mitigate their impact [10,16-28]. Literature contains important findings in the field of GHG emissions and CF calculations (a key aspect in this literature review) in different organizations, but there is certain lack of studies for intangible assets like R\&D and knowledge. There are not specific data available on how to calculate CF from knowledge-intensive organizations and neither for R\&D organizations nor technology research centers. Therefore, this study contributes to broaden literature in CF management for this type of organization. Likewise, different approaches to calculate $\mathrm{CF}$ from companies that share certain similarities with the center have been analyzed and are described briefly below in Table 1.

Table 1. Examples of GHG emissions accounting.

\begin{tabular}{|c|c|c|c|c|}
\hline Authors & Organizations & $\begin{array}{l}\text { GHG Emissions } \\
\text { Accounting }\end{array}$ & Population & Factors \\
\hline 1. Kern et al. [29] & Software company & GHG protocol & 9 & $\begin{array}{c}\text { Employees; Office } \\
\text { space; ICT } \\
\text { infrastructure }\end{array}$ \\
\hline $\begin{array}{l}\text { 2. M M.G.G Awanthi and C.M } \\
\text { Navaratne [30] }\end{array}$ & $\begin{array}{c}\text { National } \\
\text { Administrative } \\
\text { Division } \\
\text { (Sri Lanka) }\end{array}$ & GHG protocol & 110 & Scope $1,2,3$ * \\
\hline $\begin{array}{l}\text { 3. B. Ridhosaria and A. } \\
\text { Rahmana [31] }\end{array}$ & $\begin{array}{c}\text { Universitas } \\
\text { Pertamina-Jakarta } \\
\text { (Indonesia) }\end{array}$ & $\begin{array}{c}\text { Intergovernmental } \\
\text { Panel on Climate } \\
\text { Change (IPCC) }\end{array}$ & 2621 & $\begin{array}{c}\text { Electricity } \\
\text { Transportation } \\
\text { Waste generation }\end{array}$ \\
\hline \multirow[t]{2}{*}{ 4. R. Mendoza-Flores et al. [32] } & $\begin{array}{c}\text { Autonomous } \\
\text { Metropolitan } \\
\text { University } \\
\text { (Mexico) }\end{array}$ & GHG protocol & 2750 & Scope $1,2,3 *$ \\
\hline & $\begin{array}{l}\text { This technology } \\
\text { center (R\&D } \\
\text { projects on ICT) }\end{array}$ & GHG protocol & 140 & Scope $1,2,3$ * \\
\hline
\end{tabular}

* Explained in Section 2.3.4. Definition of calculation boundaries; Table 2.

The aforementioned studies provided useful elements to compare parameters and measurements with those of the center. There are similarities in data collection, although there are certain differences in the implementation of results. In the first case, a primary objective was to measure the impact of employee commuting; however, this center did not consider these data in the current assessment. In the second case, there were a number of similarities (e.g., number of employees, organization boundaries, data collection) between the division in Sri Lanka and this center. Regarding the rest of the cases, in the Indonesian university the greatest contribution to CF was electricity consumption, while in the Mexican university it was transportation and travel, just like our center. However, emission accounting provides an added value to our center, since GHG emissions data were used not only to 
determine its evolution and contribution to CF but also as a factor to be included in the assessment of the environmental aspects identified in accordance with ISO 14001.

\subsection{Methodology}

As indicated in Figure 1, the basis of the current research was to implement methodology to determine GHG emissions and calculate $\mathrm{CF}$ in an organization in which the main asset is knowledge. Applied research is the main activity of the organization, although fundamental research is also conducted, and experimental developments are undertaken. Several innovation types are created, including incremental for continuous improvement of the core business, and radical or disruptive for major changes. Innovation is applied in several areas, such as organizational, management, marketing, business models, and technology, which is the most important aspect.
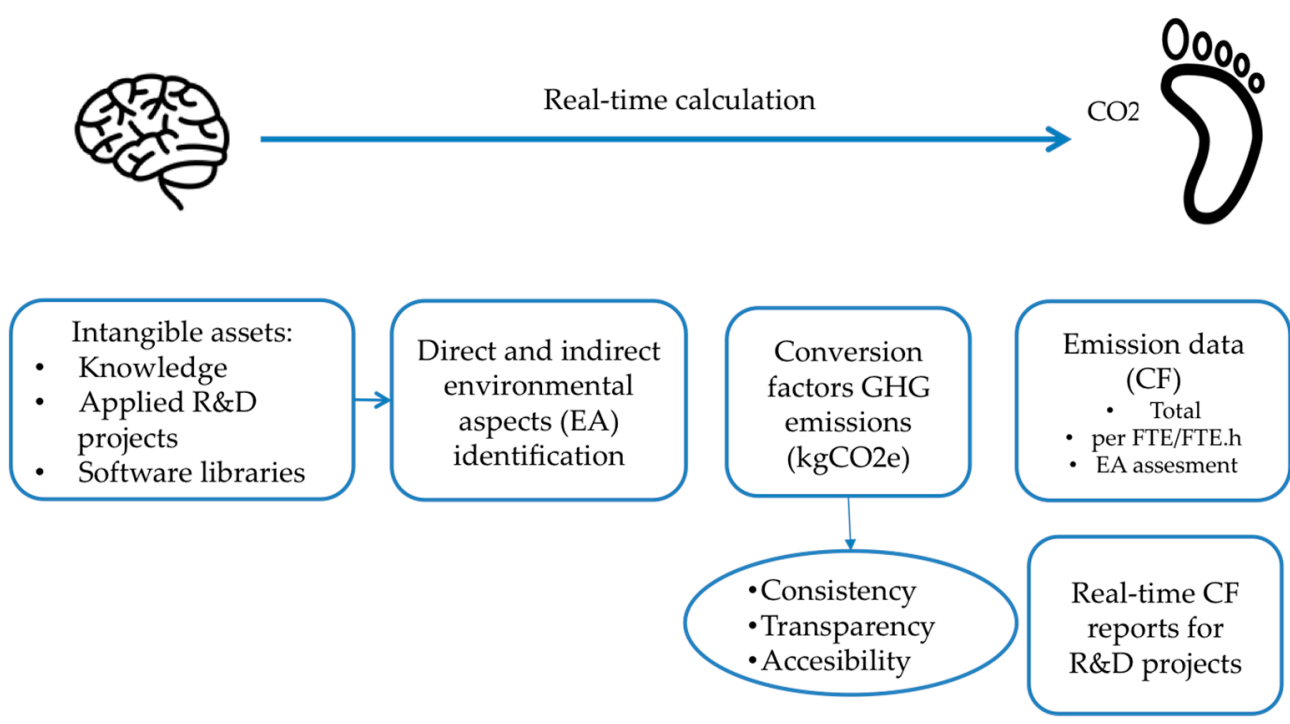

Figure 1. GHG emissions from intangible assets; FTE: full time equivalent; FTE.h: full time equivalent per hour worked.; CF: carbon footprint; GHG: greenhouse gases; EA: environmental aspects; $\mathrm{kgCO}_{2} \mathrm{e}$ : kilograms of carbon dioxide equivalent.

\subsubsection{Framework for CF Calculation}

GHG emissions to the atmosphere, caused directly and indirectly by daily activities, define the CF of any entity. CF is a concept under an umbrella term, environmental footprint, which relates to different footprint concepts, each focusing on a particular environmental concern (e.g., limited land and fresh water, climate change, and so forth), and measures either resource appropriation or waste generation, or both [33].

$\mathrm{CF}$ data contain information about effects on climate change and water usage. All data obtained are intermediate indicators of the impact pathway before the eventual damage occurs that could have adverse effects on human health, ecosystems, and resource availability [34].

\subsubsection{Characteristics of GHG Emissions of the Center}

GHG emissions generated directly or indirectly by the activities of the center are classified as diffuse and are defined as non-channeled emissions (e.g., emissions not channeled through exhaust stacks). Such emissions originate from multiple sources, such as transportation, waste management, residential, fluorinated gas leakage, agriculture, livestock, and industries. Owing to difficulties in monitoring these sources, avoiding or mitigating their environmental impact is associated with a greater awareness of environmental issues. According to data published in 2016 [35], these emissions amounted to $10.6 \mathrm{MtCO}_{2} \mathrm{e}$, accounting for $56 \%$ of the total GHG emissions in Basque Country. In view 
of the above, calculating and employing the carbon footprint as a significant factor would well serve to promote awareness in the entire organization. Therefore, an organization such as this center, with diffuse emissions, clearly contributes to climate change.

\subsubsection{Identification of Environmental Aspects}

In accordance with the ISO 14001 standard, to include CF calculation as a factor in assessing environmental aspects requires identifying which aspects of activities could have negative effects on the environment. Such consideration includes effects such as depletion of natural resources, waste generation, water pollution, and an increase in GHG. Accordingly, the center identified the following environmental aspects:

- consumption (e.g., water, fuel, transport, project travel, energy, material use, and paper);

- non-dangerous waste (e.g., paper and board, packaging, and domestic waste);

- dangerous waste (e.g., electrical and electronic equipment, batteries, and printing materials);

- eventual leakage of fluorinated greenhouse gases from the air-conditioning system.

\subsubsection{Definition of Calculation Boundaries}

To start measuring GHG emissions, 2017 was chosen as the base year, and from this year onward all collected data on consumption and waste were entered into the center database. All the units and departments of the center were included in the measurement of emissions. The entire center (all divisions) is managed by one top management team; therefore, the organizational boundary comprises the organization as a whole. GHG accounting with respect to the operational boundary was conducted according to the three scopes proposed by the GHG Protocol [36], namely

- scope 1: direct emissions from activities owned or controlled by the organization (e.g., own vehicle fuel, possible GHG leakage from cooling systems)

- $\quad$ scope 2: indirect emissions associated with purchased electricity

- scope 3: indirect emissions from center activities that occur at sources outside its control and are not classified as scope 2 (e.g., transport, business travel, hotel stay, material consumption, and waste).

\subsubsection{Selection of Conversion Factors}

Conversion factors facilitate the calculation of $\mathrm{CO}_{2}$ emissions by multiplying activity data, expressed in their respective international units and converted into kilograms of carbon dioxide equivalent $\left(\mathrm{kgCO}_{2} \mathrm{e}\right)$. CO2e is the universal unit of measurement to indicate the global warming potential (GWP) of GHGs, expressed in terms of the GWP of one unit of carbon dioxide (See Formula (1)). We consulted numerous reference sources to select the most appropriate conversion factors, considering certain selection criteria such as accessibility, consistency, and transparency in revisions and updates. Every year, during the first months of the year, conversion factors are reviewed and updated.

$$
\text { GHG }\left(\mathrm{kg} \mathrm{CO}_{2} \mathrm{e}\right)=\text { aspect quantity data } \mathrm{x} \text { conversion factor, }
$$

\subsubsection{Application of Conversion Factors}

Most conversion factors were used directly as defined in the chosen source. In certain instances, suitable factors needed to be calculated specifically, e.g., using average values when slight differences exist among the sources (e.g., hotel stays, rail travel, car trips, and the like) or using ad hoc factors that can be calculated for specific aspects and crosschecked against calculators from relevant sources (e.g., air travel), as explained further below.

In Table 2, examples of conversion factors for each identified environmental aspect (consumption and waste) and related references sources are described. 
Table 2. Examples of conversion factors used.

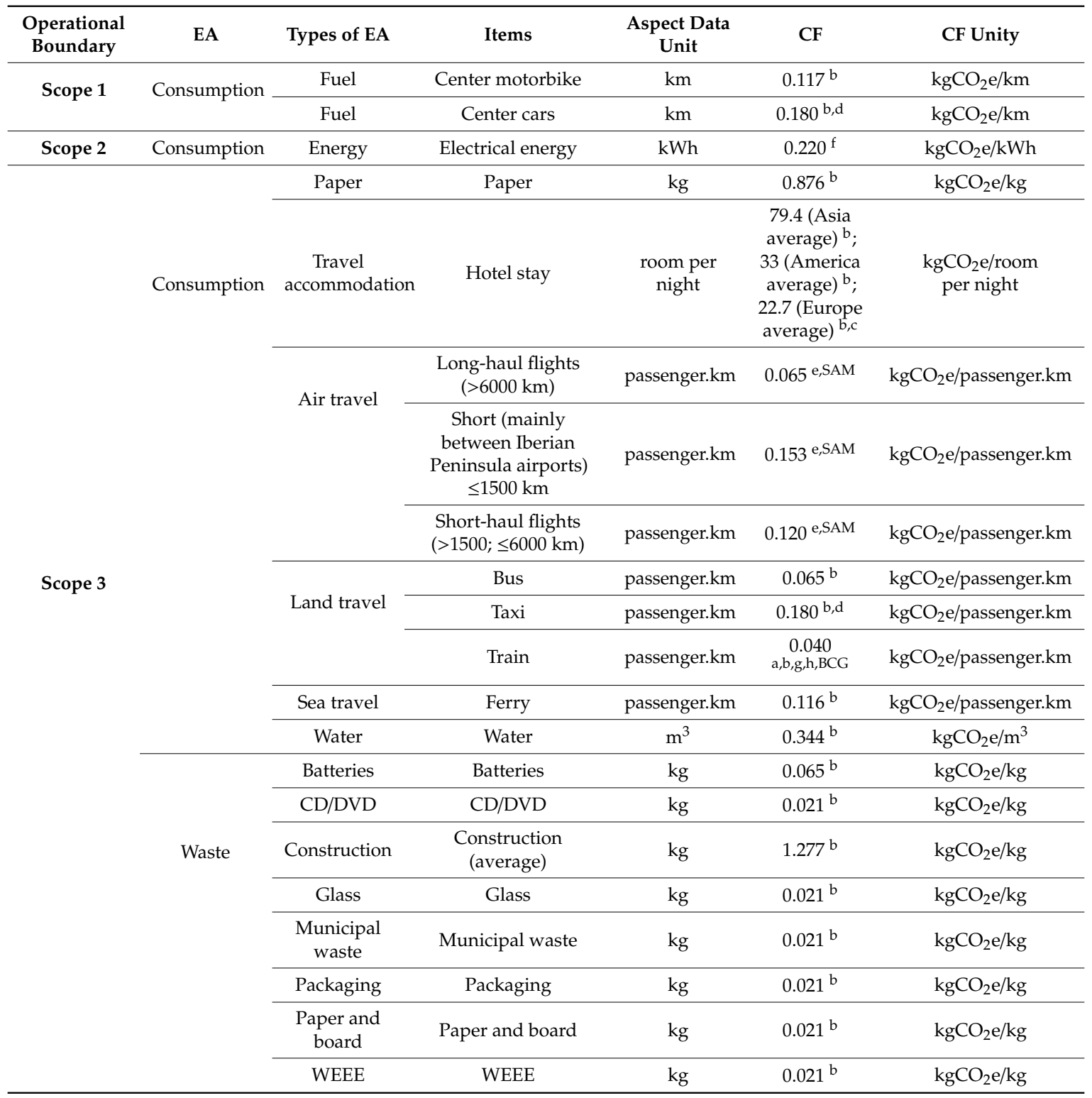

Reference sources for conversion factors: a. Community of European Railway and Infrastructure Companies (CER); b. Department for Environment, Food and Rural Affairs of the UK (DEFRA); c. Ecology and Development Foundation (ECODES, Spain); d. Institute for Energy Diversification and Saving (IDAE); e. International Civil Aviation Organization (ICAO); f. Red Eléctrica Española/Spanish Electrical Grid (REE); g. Red Nacional de los Ferrocarriles Españoles/National Network of Spanish Railways (RENFE); h. Société nationale des chemins de fer français/National Society of French Railways (SNCF). Other sources for consulting and contrasting information: Basque Country Government (BCG) Ministry for the Ecological Transition (Spain) (MITECO); Spanish Office of Climate Change (OECC). Other references: CF: Conversion factor; EA: environmental aspect; SAM: statistical analysis of means; WEEE: Waste Electrical and Electronic Equipment.

\section{CF Relevant to Transport}

As regards diffuse emissions, special attention must be given to the transport activities of the center because of the environmental effects of transport. Most projects require travel and the mobility of researchers, and it is therefore important to ensure the best estimate in this regard over the life cycle of a project. In this research, $\mathrm{CO}_{2}$ emissions were calculated in a sample of 1000 project travel occasions, using and checking factors from various sources. In general, the magnitude considered was distance travelled measured in kilometers for all means of transport, except cars, for which factors of fuel consumptions (in liters) have also been considered. For comparing both measurements 
(in kilometers and in liters), a statistical analysis of arithmetic means was conducted by applying a z-test (for comparison of arithmetic means) to a sample of car travel by 938 employees.

As the results showed, there was no significant difference between the means $(\mathrm{P}>\alpha$; where $\alpha$ level of significance $=0.05$ ) (Table 3 ), and for unifying all measurements, the center adopted the distance travelled for all of them, expressed as:

- $\quad \mathrm{kgCO}_{2} / \mathrm{km}$, for center-owned vehicles, included in scope 1;

- $\mathrm{kgCO}_{2}$ /passenger.km (emissions per kilometer travelled by one passenger), for the rest of the means of transport (road, rail, air, and sea), included in scope 3.

Table 3. Land travel: statistical analysis of means (z-test).

\begin{tabular}{ccccccccc}
\hline $\begin{array}{c}\mathbf{A V} \\
\mathbf{k g C O}_{\mathbf{2}} \mathbf{e} / \mathbf{k m}^{\mathbf{1}}\end{array}$ & $\begin{array}{c}\mathrm{AV} \\
\mathbf{k g C O}_{\mathbf{2}} \mathbf{e} / \mathbf{l}^{\mathbf{2}}\end{array}$ & $\mathrm{VAR}^{\mathbf{1}}$ & $\mathrm{VAR}^{2}$ & $\mathrm{NO}$ & $\mathbf{H M D}$ & $\mathbf{z}$ & $\begin{array}{c}\mathbf{P}(\mathbf{Z} \leq \mathbf{z}) \\
\text { two-Tail }\end{array}$ & $\begin{array}{c}\mathbf{z} \text { Critical } \\
\text { two-Tail }\end{array}$ \\
\hline 30.32 & 28.46 & 1411.96 & 1248.39 & 938 & 0 & 1.67 & 0.27 & 1.96 \\
\hline $\begin{array}{l}{ }^{1} \text { Conversion factor for distance travelled: } 0.18 \\
\text { 2.6 kg CO2/l (average value); } \mathrm{AV} \text { : average value; } \mathrm{CMD} / \mathrm{km} \text { (average value); }{ }^{2} \text { Conversion factor for fuel consumption: }\end{array}$ \\
VAR: variance.
\end{tabular}

CF Relevant to Air Travel

Center employees often travel by air, which contributes significantly to GHG emissions; therefore, we used conversion factors that facilitate realistic, as far as possible, estimates of the associated emissions. We employed the calculator designed by the International Civil Aviation Organization [18] as a reference source to determine the emissions from a sample of 304 air travel occurrences. The International Civil Aviation Organization (ICAO) calculator is a database containing the best available public data from several sources, and it considers several factors such as aircraft type, fuel, specific route, and passenger and cargo loads. In addition, this tool facilitates calculating air travel emissions for one to three legs, enabling greater accuracy in the results. We compared these data with those obtained by applying conversion factors the center had selected for three distance-travelled legs. Statistical analysis of means for both measurements was made by applying a z-test analysis, the results of which indicated that $P>\alpha$ (where $\alpha$ level of significance $=0.05)$ (Table 4$)$, showing no statistically significant difference between the means. Therefore, for simplicity of calculation, the selected conversion factors were adopted.

Table 4. Air travel: statistical analysis of means (z-test).

\begin{tabular}{cccccccccc}
\hline $\begin{array}{c}\text { Distance } \\
\text { Travelled (km) }\end{array}$ & $\begin{array}{c}\mathrm{AV} \\
\mathbf{k g C O}_{\mathbf{2}} \mathbf{e} / \mathbf{k m}^{\mathbf{1}}\end{array}$ & $\begin{array}{c}\mathrm{AV} \\
\mathbf{k g C O}_{\mathbf{2}} \mathbf{e} / \mathbf{1}^{2}\end{array}$ & $\mathrm{VAR}^{\mathbf{1}}$ & $\mathrm{VAR}^{2}$ & $\mathrm{NO}$ & $\mathbf{H M D}$ & $\mathbf{z}$ & $\begin{array}{c}\mathbf{P}(\mathrm{Z} \leq \mathrm{z}) \\
\text { two-Tail }\end{array}$ & $\begin{array}{c}\mathbf{z} \text { Critical } \\
\text { two-Tail }\end{array}$ \\
\hline$\leq 1500$ & 147.61 & $\begin{array}{c}143.11(\mathrm{CF}: \\
0.153)\end{array}$ & 3336.01 & 1749.59 & 117 & 0 & 0.68 & 0.68 & 1.96 \\
\hline$>1500$ or $\leq 6000$ & 338.65 & $\begin{array}{c}337.23(\mathrm{CF}: \\
0.12)\end{array}$ & $11,215.83$ & $15,390.21$ & 154 & 0 & 0.11 & 0.91 & 1.96 \\
\hline$>6000$ & 1076.49 & $\begin{array}{c}1137.47(\mathrm{CF}: \\
0.065)\end{array}$ & $370,166.30$ & $224,938.30$ & 33 & 0 & -0.45 & 0.65 & 1.96 \\
\hline
\end{tabular}

${ }^{1}$ Calculated by ICAO calculator; ${ }^{2}$ Calculated by using the center's own conversion factors (CF); AV: average value; HMD: hypothesized mean difference; NO: number of observations; VAR: variance.

\section{Results}

\section{1. $C F$ as an Environmental Indicator}

\subsubsection{CF Calculation and Report}

To routinely calculate GHG emissions, the center developed a computer application integrated with its enterprise resource planning (ERP), whereby all employees in the organization could determine 
the emissions generated during their daily activities (shown in Table 5). This report includes the contribution rates of each aspect to the $\mathrm{CF}$, expressed as percentages, which were applied as new criteria to assess environmental aspects, as explained below.

Table 5. Example of CF report.

\begin{tabular}{ccccc}
\hline $\begin{array}{c}\text { Type of Environmental } \\
\text { Aspects }\end{array}$ & $\mathbf{k g ~ C O} \mathbf{e}^{*}$ & $\mathbf{k g ~ C O} \mathbf{2}$ e/FTE & \% Contribution to CF & kg CO $\mathbf{2} / \mathbf{F T E} . \mathbf{h}$ \\
\hline Electrical energy & $57,726.2$ & 461.59 & $33.1 \%$ & 0.2832 \\
\hline Paper consumption & 572.9 & 4.58 & $0.3 \%$ & 0.0028 \\
\hline Vehicles & $23,678.6$ & 189.34 & $13.6 \%$ & 0.1162 \\
\hline Accommodation & $17,438.6$ & 139.44 & $10.0 \%$ & 0.0855 \\
\hline Bus & 610.2 & 4.88 & $0.3 \%$ & 0.0030 \\
\hline Flights & $73,327.9$ & 586.34 & $42.0 \%$ & 0.3597 \\
\hline Train & 921.6 & 7.37 & $0.5 \%$ & 0.0045 \\
\hline WEEE & 12.8 & 0.10 & $0.007 \%$ & 0.0001 \\
\hline Water consumption & 123.0 & 0.98 & $0.070 \%$ & 0.0006 \\
\hline Municipal waste & 30.2 & 0.24 & $0.017 \%$ & 0.0001 \\
\hline Waste batteries & 56.5 & 0.45 & $0.032 \%$ & 0.0003 \\
\hline Waste packaging & 11.3 & 0.09 & $0.006 \%$ & 0.0001 \\
\hline Wastepaper and waste & 27.3 & 0.22 & $0.016 \%$ & 0.0001 \\
\hline board & $174,536.9$ & $1,395.63$ & $100 \%$ & 0.8562 \\
\hline Total & FTE $2018: 125.06 ;{ }^{*}$ Data from 2018. & &
\end{tabular}

Emissions data can be expressed in the following ways, as the information is required:

- $\quad$ in $\mathrm{kgCO}_{2} \mathrm{e}$ (total) to monitor global monthly or yearly emissions;

- in $\mathrm{kgCO}_{2} \mathrm{e} / \mathrm{FTE}$ (FTE is the full-time equivalent or hours worked by one employee on a full-time annual basis) to break down data by employees into research area, department, activity, and so forth;

- in $\mathrm{kgCO}_{2} \mathrm{e} / \mathrm{FTE} . \mathrm{h}$ (FTE.h is the calculation per hour worked by one employee) to estimate the expected emissions per projects (e.g., to be applied in project tenders), or to monitor emissions in ongoing projects.

In Table 6, an example of a CF report shows project emissions data related to travel emissions. Such emissions had a marked effect on the CF of the center, and project managers can implement mitigation or reduction actions directly, over the course of the project. As regards CF estimates and CF final data, they additionally comprise other consumption and waste emissions, of which control resides in general management (e.g., electricity, water, and the like). 
Table 6. Example of CF report of R\&D projects.

\begin{tabular}{|c|c|c|}
\hline \multicolumn{2}{|c|}{ R\&D Project $C^{1}$} & $\mathrm{kgCO}_{2} \mathrm{e}$ \\
\hline \multirow{6}{*}{$\begin{array}{l}\text { GHG emissions of project travel } \\
\text { (Direct data entry) }{ }^{3}\end{array}$} & Flights & 2380 \\
\hline & Vehicles & 716.67 \\
\hline & Bus & 13 \\
\hline & Train & 0 \\
\hline & Accommodation & 356.8 \\
\hline & Total & 3466.47 \\
\hline CF estimate ${ }^{4}$ & $\begin{array}{l}\text { Planned hours at the project start } \\
\text { per } \mathrm{kgCO}_{2} \mathrm{e} / \mathrm{FTE} . \mathrm{h}\end{array}$ & 6635.06 \\
\hline CF final ${ }^{5}$ & $\begin{array}{l}\text { Hours worked at project closure } \\
\text { per } \mathrm{kgCO}_{2} \mathrm{e} / \text { FTE.h }\end{array}$ & $5245.39^{2}$ \\
\hline
\end{tabular}

${ }^{1}$ Project duration: 40 months (project completion date: 02/2020); ${ }^{2}$ Data from $2019 ;{ }^{3}$ Travel emissions (main contribution from projects); ${ }^{4} \mathrm{CF}$ at early projects stages; ${ }^{5} \mathrm{CF}$ at project closure.

\subsection{2. $\mathrm{CF}$ as Criterion for Impact Assessment of Environmental Aspects}

Four criteria were defined to assess the environmental effects of each aspect, namely

- physical quantity (expressed in SI units $\mathrm{m}^{3}, \mathrm{l}, \mathrm{kg}$, and others);

- percentage contribution to CF (emissions of each aspect/total center emissions);

- environmental hazardousness;

- frequency of occurrence.

As a novelty, the contribution of the GHG emissions of each aspect to global CF was incorporated with the assessment process, aiming to enhance the visibility of each effect.

Each aspect was weighed in accordance with the criteria set out by using a three-level scale of significance: 1 (less important); 2 (important); 3 (highly important), as shown in the following tables (Tables 7-10).

Table 7. Physical quantity (PQ).

\begin{tabular}{cccc}
\hline Aspect & $\mathbf{1}$ & $\mathbf{2}$ & $\mathbf{3}$ \\
\hline Consumption & Less than previous year & $\begin{array}{c}\text { Same as, or up to 20\% } \\
\text { more than previous year }\end{array}$ & $\begin{array}{c}20 \% \text { more than } \\
\text { previous year }\end{array}$ \\
\hline Waste & & & \\
\hline Water discharge & & & \\
\hline
\end{tabular}

Table 8. Aspect contribution to CF (\%) (GHG).

\begin{tabular}{cccc}
\hline All environmental & & 2 & 3 \\
\cline { 2 - 4 } aspects & $\begin{array}{c}\text { Less than or equal to 10\% or } \\
\text { non-applicable (i.e., noise) }\end{array}$ & $\begin{array}{c}\text { Greater than 10\% and } \\
\text { less than or equal to 25\% }\end{array}$ & Greater than 25\% \\
\hline
\end{tabular}


Table 9. Hazardousness (H).

\begin{tabular}{|c|c|c|c|c|}
\hline Aspect & Elements & 1 & 2 & 3 \\
\hline \multirow{5}{*}{ Consumption } & Water & $\begin{array}{c}\text { From municipal } \\
\text { water supply } \\
\text { network }\end{array}$ & $\begin{array}{l}\text { From public } \\
\text { waterway }\end{array}$ & $\begin{array}{l}\text { From underground } \\
\text { water source }\end{array}$ \\
\hline & Energy & $\begin{array}{l}\text { From renewable } \\
\text { energy sources }\end{array}$ & $\begin{array}{l}\text { From fossil fuel } \\
\text { consumption }\end{array}$ & $\begin{array}{l}\text { From nuclear } \\
\text { sources }\end{array}$ \\
\hline & Fossil fuel & LPG and hydrogen & Petrol & Diesel oil \\
\hline & Material & $\begin{array}{l}\text { No allocated } \\
\text { danger }\end{array}$ & Harmful, irritant & $\begin{array}{c}\text { Flammable, toxic, } \\
\text { corrosive, } \\
\text { contaminant }\end{array}$ \\
\hline & Paper & PEFC or FSC & $\begin{array}{l}\text { Totally or partially } \\
\text { recycled }\end{array}$ & $\begin{array}{l}\text { Not recycled, no } \\
\text { ecological criteria }\end{array}$ \\
\hline \multirow[b]{2}{*}{ Waste } & Waste & $\begin{array}{l}\text { Non-hazardous } \\
\text { waste intended for } \\
\text { recovery, recycling, } \\
\text { or re-use }\end{array}$ & $\begin{array}{c}\text { Non-hazardous } \\
\text { waste intended for } \\
\text { landfill }\end{array}$ & Hazardous waste \\
\hline & $\begin{array}{l}\text { Wastewater } \\
\text { discharge }\end{array}$ & $\begin{array}{c}\text { Into municipal } \\
\text { sewer or treatment } \\
\text { plant }\end{array}$ & $\begin{array}{c}\text { Into public } \\
\text { waterway or sea } \\
\text { without fauna or of } \\
\text { little ecological } \\
\text { importance }\end{array}$ & $\begin{array}{c}\text { Into public } \\
\text { waterway or sea } \\
\text { with fauna or of } \\
\text { ecological } \\
\text { importance }\end{array}$ \\
\hline Noise & Noise & $\begin{array}{l}\text { Industrial area or } \\
\text { similar far away } \\
\text { from houses or } \\
\text { town centers }\end{array}$ & $\begin{array}{l}\text { Industrial areas or } \\
\text { similar close to } \\
\text { residential areas }\end{array}$ & $\begin{array}{l}\text { Residential areas or } \\
\text { areas of ecological } \\
\text { importance }\end{array}$ \\
\hline
\end{tabular}

LPG: liquefied petroleum gas; PEFC: Programme for the Endorsement of Forest Certification; FSC: Forest Stewardship Council.

Table 10. Frequency of occurrence (F).

\begin{tabular}{|c|c|c|c|}
\hline Aspect & 1 & 2 & 3 \\
\hline Consumption & $\begin{array}{l}\text { Less than } 50 \% \text { of } \\
\text { duty time }\end{array}$ & $\begin{array}{c}\text { Between } 50 \% \text { and } 75 \% \text { of } \\
\text { duty time }\end{array}$ & $\begin{array}{l}\text { Between } 75 \% \text { and } 100 \% \\
\text { of duty time }\end{array}$ \\
\hline Waste & $\begin{array}{l}\text { Occasional, unexpected, } \\
\text { or unplanned occurrence }\end{array}$ & $\begin{array}{l}\text { Occasional, associated } \\
\text { with unusual but } \\
\text { expected operations }\end{array}$ & $\begin{array}{l}\text { Constant, or produced by } \\
\text { the activities themselves }\end{array}$ \\
\hline Water discharge & $\begin{array}{l}\text { Less than } 50 \% \text { of } \\
\text { duty time }\end{array}$ & $\begin{array}{c}\text { Between } 50 \% \text { and } 75 \% \text { of } \\
\text { duty time }\end{array}$ & $\begin{array}{l}\text { Between } 75 \% \text { and } 100 \% \\
\text { of duty time }\end{array}$ \\
\hline Noise & $\begin{array}{l}\text { Less than } 50 \% \text { of } \\
\text { duty time }\end{array}$ & $\begin{array}{c}\text { Between } 50 \% \text { and } 75 \% \text { of } \\
\text { duty time }\end{array}$ & $\begin{array}{l}\text { Between } 75 \% \text { and } 100 \% \\
\text { of duty time }\end{array}$ \\
\hline
\end{tabular}

Finally, using the assessment results, the level of environmental impact could be calculated for each aspect by employing Equations (2) and (3).

$$
\begin{gathered}
\text { Environmental factor }(\mathrm{EF})=(\mathrm{PQ}+\mathrm{GHG}) / 2 \times \mathrm{H}, \\
\text { Level of environmental impact }=\mathrm{EF} \times \mathrm{F},
\end{gathered}
$$

This assessment process was applied to all planned and controlled operating conditions, which could be usual (e.g., water consumption) or unusual (e.g., center vehicle maintenance). As regards emergency or unexpected events, the aspects involved (i.e., water and material consumption, GHG leakage, waste generation) were measured and computed as an extraordinary burden. 


\subsubsection{Benchmarking Exercise}

A benchmarking exercise of the CF data was conducted to compare the calculation process and methodological approaches against an organization chosen as a reference, with the results shown in Table 11. This type of practice facilitates identifying the best functional practices with a positive mindset for continuous improvement.

Table 11. Example of benchmarking exercise.

\begin{tabular}{|c|c|c|c|c|c|c|}
\hline \multirow[b]{2}{*}{ Environmental Aspect } & \multicolumn{3}{|c|}{ Technology Center } & \multicolumn{3}{|c|}{ Reference Organization } \\
\hline & 2017 & 2018 & $\Delta$ & 2017 & 2018 & $\Delta$ \\
\hline Water $\left(\mathrm{m}^{3}\right)$ & 263 & 286 & $8.75 \%$ & 2.872 million & 2.956 million & $2.9 \%$ \\
\hline Water ( $\left.\mathrm{m}^{3} / \mathrm{employee}\right)$ & 2 & 2 & $0.05 \%$ & 15 & 15 & $2.0 \%$ \\
\hline Electrical energy (kWh) & 355,372 & 270,319 & $-23.93 \%$ & 639 million & 616 million & $-3.6 \%$ \\
\hline Green energy (kWh) & 0 & 125,066 & & 473 million & 461 million & $-2.5 \%$ \\
\hline Total energy (kWh) & 355,372 & 395,385 & $11.26 \%$ & 1112 million & 1077 million & $-3.1 \%$ \\
\hline Total energy (kWh/employee) & 3090 & 3163 & $2.36 \%$ & 5681 & 5551 & $-2.3 \%$ \\
\hline Paper (kg) & 649 & 617 & $-4.92 \%$ & 20.01million & 16.7 million & $-16.5 \%$ \\
\hline Certified paper (kg) & 413 & 378 & $-8.29 \%$ & 16.97 million & 14.58 million & $-14.1 \%$ \\
\hline Paper (kg/employee) & 6 & 5 & $-12.53 \%$ & 102 & 86 & $-15.7 \%$ \\
\hline Wastepaper and waste board (kg) & 1603 & 1276 & $-20.39 \%$ & 8.97 million & 7.65 million & $-14.7 \%$ \\
\hline $\begin{array}{l}\text { Wastepaper and waste board } \\
\text { (kg/employee) }\end{array}$ & 14 & 10 & $-26.76 \%$ & 46 & 39 & $-15.2 \%$ \\
\hline \multicolumn{7}{|c|}{ GHG emissions } \\
\hline $\begin{array}{l}\text { Direct emissions (own vehicle fuel) } \\
\qquad\left(\mathrm{kgCO}_{2} \mathrm{e}\right)\end{array}$ & 11,461 & 11,753 & $0.03 \%$ & 29 million & 31 million & $6.9 \%$ \\
\hline $\begin{array}{l}\text { Indirect emissions (electricity) } \\
\qquad\left(\mathrm{kgCO}_{2} \mathrm{e}\right)\end{array}$ & 78,182 & 57,726 & $-0.26 \%$ & 374 million & 364 million & $-2.7 \%$ \\
\hline $\begin{array}{l}\text { Indirect emissions (travel } \\
\text { emissions) }\left(\mathrm{kgCO}_{2} \mathrm{e}\right)\end{array}$ & 79,336 & 85,793 & $0.08 \%$ & 126.2 million & 124.8 million & $-1.1 \%$ \\
\hline Total emissions $\left(\mathrm{kgCO}_{2} \mathrm{e}\right)$ & 168,978 & 155,272 & $-0.08 \%$ & 530 million & 521 million & $-1.7 \%$ \\
\hline $\begin{array}{c}\text { Total emissions } \\
\left(\mathrm{kgCO}_{2} \mathrm{e} / \text { employee }\right)\end{array}$ & 1469 & 1242 & $-0.15 \%$ & 2706 & 2684 & $-0.8 \%$ \\
\hline Employees & 115 & 125 & $8.7 \%$ & 195,732 & 194,027 & $-0.87 \%$ \\
\hline
\end{tabular}

\section{Discussion}

As mentioned in the introduction, this article responds to the following.

\subsection{Is an Organization Based on Intangible Assets Able to Contribute to Climate Change?}

This article makes it clear that an organization like our center, whose GHG emissions are diffuse, is capable of contributing to climate change; therefore, calculating CF can be a relevant element in controlling the environmental impact of its activities and in raising the environmental awareness of its employees.

This tool helps to assimilate the concept of CF in every activity undertaken by the center, as project managers can estimate the emissions of each project from its beginning, according to planned hours, as well as to monitor them in all phases of the project life cycle.

This application also allows determining the trend of evolution of the $\mathrm{CF}$ of the entire organization and that of each aspect it comprises, which facilitates implementing corrective or preventive actions. As an example, the decline in GHG emissions from $182,400 \mathrm{kgCO}_{2} \mathrm{e}$ in 2017 to $174,536.9 \mathrm{kgCO}_{2} \mathrm{e}$ in 2018, and showing a downward trend in 2019, resulted from remedial actions, such as purchasing an LPG (liquefied petroleum gas) vehicle for employee use, replacing fluorescent with LED lighting, increasing 
the consumption of renewable energy, encouraging the use of videoconferences as an alternative to travel, and communication actions, with environmental awareness messages addressed to all staff (e.g., videos, e-mails, environmental issues included in monthly staff meeting agenda).

\subsection{Is CF a Suitable Indicator for Measuring the Effect of RED Activities on the Environment?}

Consideration for $\mathrm{CF}$ calculation being a suitable environmental indicator include that it has been widely used and considered by scientists as a global warming indicator for many years [26,28]; several calculation tools are available for testing, comparing, and validating results; it remains a catchphrase used by the media, governments, and in business [37]; people generally associate this term with the environment and, although in some instances they might be unaware of the scope of the concept, the term is easily understood by all the employees of the center.

\subsection{Could CFP Become an Element for Raising Environmental Awareness within the Organization?}

After two years of implementing real-time reports, results show the practical value of the CF calculation in the following aspects:

- The center can make decisions to reduce the CF according to indicators and objectives and manage employees to meet those objectives.

- Data are always very relevant in all fields to identify problems and, concerning CF data, it helps to make center's employees aware about their impact on climate change and how they can improve their habits to make improvements in the global environment.

- The orientation toward acknowledging of results, rather than effort, requires a shift in researchers' thinking and behavior, not only in their work but also in their personal habits.

It is important to emphasize that, along with the communication of environmental actions, awareness was raised of consumption and waste as well as environmental accountability. This is in accordance with the measurement by general management of the effectiveness of communicating relevant strategies and objectives, which showed a positive trend $(2.3 \%)$ in the 2018 staff survey compared with that of 2017.

\section{Conclusions}

This article presents CF calculations generated by intangibles carefully described, in such a way that it can be directly implemented in other organizations. Selection criteria of conversion factors have been included. This methodology to calculate CF could therefore be applicable to all organizations and, in particular, to those (e.g., consulting companies, banks, services organizations, and the like) with diffuse emissions, which are difficult to control. In recent years, as the magnitude of the effect of emissions on climate change was not easily perceived, the center has launched specific actions to raise the environmental awareness of all employees and stakeholders. These procedures, communications, and trainings are reflected in the strategies and goals of the center. In accordance with this approach, the center uses CF data as a new criterion to be applied in environmental assessment.

This research methodology has limitations. The most significant is that it is a single-case study and has potential limitations for systematic generalization. Rather than generalizing, our aim was to enrich the body of knowledge on the CF literature. Other tools and methodologies exist. Another possible limitation is the lack of yearly data. Although two years' work was required to design and implement this methodology, there are only two years of data. The design and indicators are easy to replicate, but the implementation takes time and effort. Every implementation is conducted from an environmental and educational perspective, considering that environmental knowledge can foster environmental competence [38]. Promoting respect for the environment helps to foster the credence by employees and stakeholders that such respect is one of the ethical duties implied in professionalism [39]. For measuring people's commitment regarding the development of environmental management, specific 
questions will be included in the next staff surveys. This first step can help organizations to contribute to the way of good government. Future work would be to conduct this study in social accounting.

Author Contributions: Conceptualization, E.L.-L. and J.C.M.; Investigation, M.B.; Methodology, E.L.-L. and J.C.M.; writing —original draft preparation, M.B.; writing—review and editing, E.L.-L. E.L.-L. contributed in the conceptualization, methodology supervision and review. M.B. contributed in the investigation and writing and J.C.M. contributed in the investigation and methodology. All authors have read and agreed to the published version of the manuscript.

Funding: This research received no external funding.

Conflicts of Interest: The authors declare no conflict of interest.

\section{References}

1. European Commission. How Companies Influence Our Society: Citizens' View (Flash Eurobarometer 363); Directorate-General for Communication: Brussels, Belgium, 2013.

2. Köhler, J.; Geels, F.W.; Kern, F.; Markard, J.; Onsongo, E.; Wieczorek, A.; Alkemade, F.; Avalino, F.; Bergek, A.; Boons, F.; et al. An agenda for sustainability transitions research: State of the art and future directions. Environ. Innov. Soc. Transit. 2019, 31, 1-32. [CrossRef]

3. European Commission. Report from the Commission to the European Parliament, the Council, the European Economic and Social Committee and the Committee of the Regions on the implementation of the Circular Economy Action Plan; European Commission: Brussels, Belgium, 2019.

4. Falcone, P.M. Tourism-Based Circular Economy in Salento (South Italy): A SWOT-ANP Analysis. Soc. Sci. 2019, 8, 216. [CrossRef]

5. Morone, P.; Falcone, P.M.; Tartiu, V.E. Food waste valorisation: Assessing the effectiveness of collaborative research networks through the lenses of a COST action. J. Clean. Prod. 2019, 238, 117868. [CrossRef]

6. Loyarte, E.; García-Olaizola, I.; Posada, J.; Azua, I.; Florez-Esnal, J. Enhancing Researchers' Performance by Building Commitment to Organizational Results. Res. Manag. 2020, 64, 44-52.

7. Loyarte, E.; Olaizola, I.G.; Marcos, G.; Moral, M.; Gurrutxaga, N.; Florez-Esnal, J.; Azua, I. Model for calculating the intellectual capital of research centres. J. Intellect. Cap. 2018, 19, 787-813. [CrossRef]

8. ISO 9001. Quality Management Systems; European Committee for Standardization: Brussels, Belgium, 2015.

9. UNE 166002. REDEi Management; Spanish Association for Standardization: Madrid, Spain, 2014.

10. ISO 14001. Environmental Management System; European Committee for Standardization: Brussels, Belgium, 2015.

11. Sidiropoulos, E. Education for sustainability in business education programs: A question of value. J. Clean. Prod. 2014, 85, 472-487. [CrossRef]

12. Zareie, B.; Navimipour, N.J. The impact of electronic environmental knowledge on the environmental behaviors of people. Comput. Human Behav. 2016, 59, 1-8. [CrossRef]

13. UNFCCC. Kyoto Protocol Reference Manual on Accounting of Emissions and Assigned Amount; United Nations Framework Convention on Climate Change: Bonn, Germany, 2008.

14. United Nations General Assembly. Transforming Our World: The 2030 Agenda for Sustainable Development; General Assembly United Nations: New York, NY, USA, 2015.

15. United Nations-Agenda 21. Agenda 21. United Nations Conference on Environment E Development; United Nations Sustainable Development: New York, NY, USA, 1992.

16. ISO 14064. Greenhouse Gases-Specification with Guidance at the Organization Level for Quantification and Reporting of Greenhouse Gas Emissions and Removals; European Committee for Standardization: Brussels, Belgium, 2018.

17. DEFRA-GOV.UK. Department for Environment, Food \& Rural Affairs-GOV.UK. Available online: https: //www.gov.uk/government/publications/greenhouse-gas-reporting-conversion-factors-2018 (accessed on 10 October 2019).

18. ICAO. International Civil Aviation Organization. Available online: https://www.icao.int/environmentalprotection/CarbonOffset/Pages/default.aspx (accessed on 28 October 2019).

19. IPCC. Climate Change 2014: Synthesis Report. Contribution of Working Groups I, II and III to the Fifth Assessment Report of the Intergovernmental Panel on Climate Change; Core Writing Team, Pachauri, R.K., Meyer, L.A., Eds.; IPCC: Geneva, Switzerland, 2014. 
20. Squires, J.; Goater, A. Carbon Footprint of Heat Generation (POST-Parliamentary Office of Science and Technology-UK); The Parliamentary Office of Science and Technology: London, UK, 2016.

21. Peters, G.P. Carbon footprints and embodied carbon at multiple scales. Curr. Opin. Environ. Sustain. 2010, 2, 245-250. [CrossRef]

22. Hansson, K.; Andersson, H.; Ejhed, H.; Liljeberg, M.; Olshammar, M.; Skarman, T.; Sorme, L.; Dunso, S.C.B.; Segersson, S.M.H.I. Diffuse Emissions to Air and Water; Swedish Meteorological and Hydrological Institute: Norrköping, Sweden, 2012.

23. Boström, M. A missing pillar? Challenges in theorizing and practicing social sustainability: Introduction to the special issue. Sustain. Sci. Pract. Policy 2012, 8, 3-14. [CrossRef]

24. Basque Government. Climate Change Strategy of the Basque Country to 2050; Basque Government: Vitoria-Gasteiz, Spain, 2015.

25. Carbon Trust, Global e-Sustainability Initiative (Gesi). ICT Sector Guidance Built on GHG Protocol; GHG Protocol: Geneva, Switzerland, 2017.

26. Caro, D. Carbon Footprint. In Encyclopedia of Ecology; Elsevier: Amsterdam, The Netherlands, 2019; pp. 252-257.

27. Rahman, F.; O’Brien, C.; Ahamed, S.I.; Zhang, H.; Liu, L. Design and implementation of an open framework for ubiquitous carbon footprint calculator applications. Sustain. Comput. Informatics Syst. 2011, 1, 257-274. [CrossRef]

28. Wang, N.; Guo, Z.; Meng, F.; Wang, H.; Yin, J.; Liu, Y. The circular economy and carbon footprint: A systematic accounting for typical coal-fuelled power industrial parks. J. Clean. Prod. 2019, 229, 1262-1273. [CrossRef]

29. Kern, E.; Dick, M.; Naumann, S.; Hiller, T. Impacts of software and its engineering on the carbon footprint of ICT. Environ. Impact Assess. Rev. 2015, 52, 53-61. [CrossRef]

30. Awanthi, M.G.G.; Navaratne, C.M. Carbon Footprint of an Organization: A Tool for Monitoring Impacts on Global Warming. Procedia Eng. 2018, 212, 729-735. [CrossRef]

31. Ridhosari, B.; Rahman, A. Carbon footprint assessment at Universitas Pertamina from the scope of electricity, transportation, and waste generation: Toward a green campus and promotion of environmental sustainability. J. Clean. Prod. 2020, 246, 119172. [CrossRef]

32. Mendoza-Flores, R.; Quintero-Ramírez, R.; Ortiz, I. The carbon footprint of a public university campus in Mexico City. Carbon Manag. 2019, 10, 501-511. [CrossRef]

33. Hoekstra, A.; Wiedmann, T. Humanity's unsustainable environmental footprint. Science 2014, 344, $1114-1117$. [CrossRef] [PubMed]

34. Huijbregts, M.A.J.; Steinmann, Z.J.; Elshout, P.M.; Stam, G.; Verones, F.; Vieira, M.; Zijp, M.; Hollander, A.; van Zelm, R. ReCiPe2016: A harmonised life cycle impact assessment method at midpoint and endpoint level. Int. J. Life Cycle Assess. 2017, 22, 138-147. [CrossRef]

35. Ihobe (Basque Country). Perfil Ambiental de Euskadi 2018; Ihobe, Public Company for Environmental Management: Bilbao, Spain, 2019.

36. GHG Protocol (WRI and WBCSD). Greenhouse Gas Protocol. Available online: https://ghgprotocol.org (accessed on 3 October 2019).

37. Wiedmann, T.; Minx, J. Definition of Carbon Footprint. In Ecological Economics Research Trend; Nova Science Publishers: Hauppauge, NY, USA, 2008.

38. Liefländer, A.K.; Bogner, F.X. Educational impact on the relationship of environmental knowledge and attitudes. Environ. Educ. Res. 2018, 24, 611-624. [CrossRef]

39. Pulido, M.P. Ethical Dimension in Libraries and Other Organisational Information Services. In Ethics Management in Libraries and Other Information Services; Elsevier: Amsterdam, The Netherlands, 2018; pp. 53-74.

(C) 2020 by the authors. Licensee MDPI, Basel, Switzerland. This article is an open access article distributed under the terms and conditions of the Creative Commons Attribution (CC BY) license (http://creativecommons.org/licenses/by/4.0/). 